
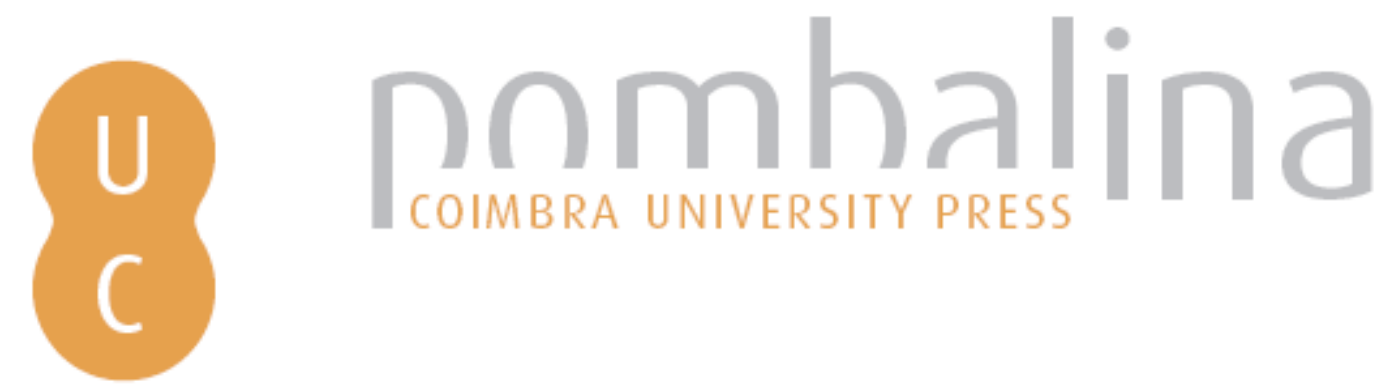

\title{
Is remote sensing a good method to define forest fire resilience? A particular case in the South-eastern of the Iberian Peninsula
}

\author{
Autor(es): $\quad$ Hedo, Javier; Rubio, Eva; Dadi, Tarek; López-Serrano, Francisco \\ Ramón; Alfaro-Sánchez, Raquel; Moya, Daniel; Heras, Jorge de las
}

Publicado por: Imprensa da Universidade de Coimbra

URL persistente:

URI:http://hdl.handle.net/10316.2/34192

DOI:

DOI:http://dx.doi.org/10.14195/978-989-26-0884-6_63

Accessed : $\quad$ 26-Apr-2023 09:49:54

A navegação consulta e descarregamento dos títulos inseridos nas Bibliotecas Digitais UC Digitalis, UC Pombalina e UC Impactum, pressupõem a aceitação plena e sem reservas dos Termos e Condições de Uso destas Bibliotecas Digitais, disponíveis em https://digitalis.uc.pt/pt-pt/termos.

Conforme exposto nos referidos Termos e Condições de Uso, o descarregamento de títulos de acesso restrito requer uma licença válida de autorização devendo o utilizador aceder ao(s) documento(s) a partir de um endereço de IP da instituição detentora da supramencionada licença.

Ao utilizador é apenas permitido o descarregamento para uso pessoal, pelo que o emprego do(s) título(s) descarregado(s) para outro fim, designadamente comercial, carece de autorização do respetivo autor ou editor da obra.

Na medida em que todas as obras da UC Digitalis se encontram protegidas pelo Código do Direito de Autor e Direitos Conexos e demais legislação aplicável, toda a cópia, parcial ou total, deste documento, nos casos em que é legalmente admitida, deverá conter ou fazer-se acompanhar por este aviso.

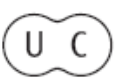




\section{ADVANCES IN}

Forest Fire

\section{RESEARCH}

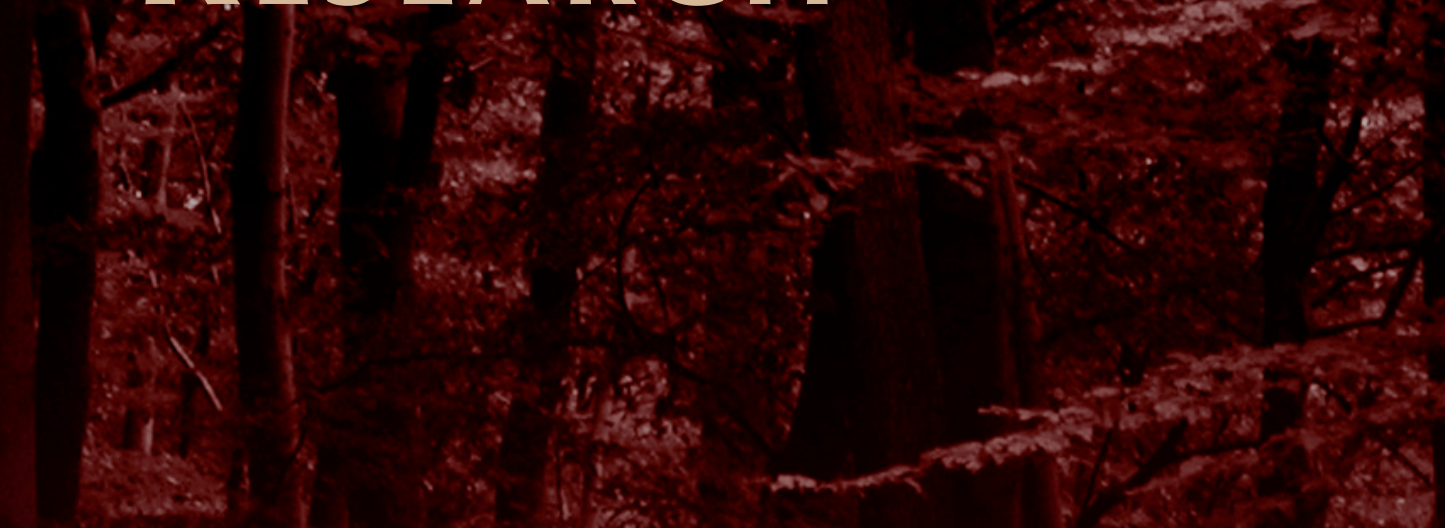

\section{DOMINGOS XAVIER VIEGAS}

\section{EDITOR}




\title{
Is remote sensing a good method to define forest fire resilience? A particular case in the South-eastern of the Iberian Peninsula
}

\author{
Javier Hedo ${ }^{\mathrm{a}}$, Eva Rubio ${ }^{\mathrm{b}}$, Tarek Dadi ${ }^{\mathrm{c}}$, Francisco Ramón López-Serrano ${ }^{\mathrm{c}}$, Raquel Alfaro-Sánchez ${ }^{\mathrm{a}}$,
} Daniel Moya $^{\mathrm{a}}$, Jorge de las Heras ${ }^{\mathrm{a}}$

${ }^{a}$ Department of Plant Production and Agricultural Technology. School of Agricultural Engineering of Albacete. University of Castilla-La Mancha. Campus University s/n 02071, Albacete. Javier.Hedo@gmail.com; R.Alfarosanchez@gmail.com; Daniel.Moya@uclm.es; Jorge.Heras@uclm.es

${ }^{b}$ Department of Applied Physics, School of Industrial Engineering of Albacete. University of Castilla-La Mancha. Campus University s/n 02071, Albacete.EvaMaria.Rubio@uclm.es

${ }^{c}$ Department of Genetics and Agroforestry Science and Technology, School of Agricultural

Engineering of Albacete. University of Castilla-La Mancha. Campus University s $/$ 02071, Albacete. Fco.Lopez@uclm.es; Tarek.Dadi@uclm.es

\begin{abstract}
Fire is one of the most drastic disturbances in forest ecosystems, particularly in Mediterranean ecosystems. Global change, including climate change and land use changes, is strengthening the rising of frequency and intensity of them. The knowledge of the resilience of the main Mediterranean ecosystems would allow defining policies and actions to protect the most vulnerable species.

One of the problems that the concept of resilience presents it is to be a concept associated to the dynamic of the ecosystem and there is no definition to quantify in a normalized and standardized way. This work propose an original methodology that involves the definition of type curves of recovery based on a time series of NDVI data, from Landsat satellite images, and the analysis of the potential changes in the taxonomic composition of the ecosystem after fire. We present the analysis of two areas affected by forest fires in the southeast of the Iberian Peninsula. It involves representative plant communities in this region, specifically esparto-grassland, esparto and rosemary shrubbery, and Aleppo pine forest.
\end{abstract}

Keywords: resilience, site quality, landscape ecology, forest dynamics.

\section{Introduction}

Fire is one of the main drastic disturbances in forest ecosystems, mainly in Mediterranean ecosystems, and plants have developed traits to cope with fire. Resilience has been defined as the capacity of an ecosystem to respond to a disturbance by resisting damage and recovering in a relatively short period of time in plant communities. The resilience is a function of the composite resiliences of the assemblage of species populations (Keeley 1986).

Global change, climate change and changes in land use or land cover, modified fire regime in Southeastern Spain in the last three decades (Pausas 2004). The changes promoted an increase in the number and recurrence of wildfires, its intensity and severity, burned surface and the period of fire risk. Those changes in fire regime could induce changes in the climax stage of plant community and/or ecosystems, relegated to secondary stages in the succession or, even, to paraclimax stages (San Miguel Ayanz et al., 2012). It implies a decrease in productivity and a reduction in plant diversity, in addition to variations in spatial distribution and vegetation structure. Forest management based on natural disturbances could maintain and restore ecological resilience (Drever et al., 2006) which should be taken into account in planning and policies to protect the less resilient species and improve it.

Tools helping decision makers should include analysis of resilience and adaptive resource management based in scientific knowledge. The concept of resilience is associated with ecosystem dynamics and different approaches have been developed for concrete cases of study, however, there is still a lack 
regarding to obtain a normalized and standardized method to quantify relative resilience. The main objective of the current framework was to develop a tool for landscape-scale monitoring and prediction of vegetation resilience, related to management objectives.

\section{Methods}

\subsection{Study area}

This work was carried out in two areas burnt in 1994 in the municipality of Hellin (province of Albacete). Before fire, mature and natural Aleppo pine forests (Pinus halepensis Mill) and espartograsslands (Macrochloa tenacissima (L.) Kunth) covered the study area. The study area was characterized as a semiarid type and the potential natural vegetation was a shrubland of Quercus coccifera L. (Rhamno lycioidis - Quercetum cocciferae sigmetum) (Rivas-Martinez 1987). After fire, the vegetation was mainly composed of Aleppo pine, esparto grass and rosemary (Rosmarinus officinalis L.). Physical and climatic characterization of the study areas is shown in Table 1.

Table 1. Physical and climatic characterization corresponding to the analysed areas. Rainfall and temperature were calculated for the last 30 years

\begin{tabular}{|c|c|c|}
\hline Site & "Sierra de los Donceles" & "Peñalavada" \\
\hline Date & $04 / 01 / 1994$ & $07 / 19 / 1994$ \\
\hline Slope $\left({ }^{\mathbf{}}\right)$ & $18-35$ & ene-40 \\
\hline Aspect & All & All \\
\hline Altitude (m) & $618-770$ & $427-825$ \\
\hline Soil type (IGME, 2013) & Aridisols & Entisols \\
\hline Rainfall (mm) & 275 & 285 \\
\hline Temperature $\left.\mathbf{(}^{\mathbf{C}} \mathbf{C}\right)$ & 15.6 & 16.1 \\
\hline
\end{tabular}

\subsection{Experimental design}

Resilience concept includes multiple aspects, such as taxonomic composition and pre-fire community structure changes, changes in ecosystem functions and impacts of processes rates (Holling, 1973). In this work it is formulated a methodological approximation to the resilience concept, centered on the study of plant community composition changes (successional stages) and on structure changes (recovery dynamics). In addition, those changes are analyzed in terms of plant community external factors, as fire severity and site quality. Here, the site quality concept is approximated by the amount of vegetation before the fire.

In particular, the study of changes in the taxonomic composition of communities after fire has been carried out based on pre-and post-fire cartography and forest inventories (Table 2). Structural changes in vegetation have been determined from the estimation of the recovery dynamics based on the amount and greenness of the vegetation. For that end, it has been proposed the assessment of the temporal evolution curves of the Normalized Difference Vegetation Index (NDVI) in the burnt areas. We use seventeen Landsat images, all of them distributed in the period 1992-2011. The acquisition dates of all Landsat images used were in spring, to avoid potential seasonal changes in NDVI due to phenological variations. Landsat images were also used to determine fire severity in terms of the differenced Normalized Burn Ratio (dNBR) (Key and Benson, 2006). For each pixel in the image of the study areas a record with all the fields from the databases showed in Table 2 was assigned. This information was used to analyse the changes in the taxonomic composition of communities, to define site quality and resilience. 
Table 2. List of databases, cartography and satellite imagery used in this work.

\begin{tabular}{|l|l|}
\hline Database & Source \\
\hline Spanish Forest Map 1:200,000 (MFE200) & MMA \\
\hline Spanish Forest Inventory 2(IFN2) & MMA \\
\hline Forest Inventory Spanish 3 (IFN3) & MMA \\
\hline Spanish Forest Map 1:50,000 (MFE50) & MMA \\
\hline Climatological DB (1980-2012) & AEMET \\
\hline Digital Terrain Model (DTM) & IDE-CLM \\
\hline Map 1:1,000,000 lithologies of Spain & IGME \\
\hline Soil Map of Spain 1:1,000,000 & IG ME \\
\hline Series vegetation Rivas-Martínez & MMA \\
\hline Landsat 5/7 and derivatives (NDVI, DNBR) & USGS, National Remote Sensing Plan \\
\hline
\end{tabular}

\section{Results}

The vegetation present in the area was classified into five general plant formations and two plant subtypes in order to analyse their different post-fire behaviours (Table 3).

Table 3. Plant formations in the study area

\begin{tabular}{|c|c|c|c|c|}
\hline & & $\begin{array}{c}\text { Plant } \\
\text { formation }\end{array}$ & Name & Description \\
\hline \multirow{4}{*}{$\stackrel{\circ}{8}$} & \multirow{3}{*}{$\begin{array}{l}\infty \\
\infty \\
\infty\end{array}$} & Formation 1 & Esparto grassland & Mainly esparto grassland \\
\hline & & Formation 2 & Grass-shrub & $\begin{array}{l}\text { Land associated with scrub grassland. Scrub surface } \\
\text { does not exceed } 20 \% \text {. }\end{array}$ \\
\hline & & Formation 3 & Shrub & Predominance of shrubs and suffrutescent plants. \\
\hline & \multirow{3}{*}{$\stackrel{\circ}{n}$} & Formation 4 & $\begin{array}{l}\text { Aleppo pine open } \\
\text { forest }\end{array}$ & $\begin{array}{l}\text { Aleppo pine high pole wood forest (canopy cover } \\
\text { fraction } 10 \% \text { ) }\end{array}$ \\
\hline$\delta^{e}$ & & \multirow{2}{*}{ Formation 5} & \multirow{2}{*}{$\begin{array}{l}\text { Aleppo pine } \\
\text { dense forest }\end{array}$} & $\begin{array}{l}\text { 5.1. Aleppo pine high pole wood forest (canopy cover } \\
\text { fraction } 30 \% \text { ) }\end{array}$ \\
\hline$\stackrel{0}{0}$ & & & & $\begin{array}{l}\text { 5.2. Aleppo pine high pole wood forest (canopy cover } \\
\text { fraction } 60 \% \text { ) }\end{array}$ \\
\hline
\end{tabular}

\subsection{Taxonomic composition changes}

Changes in land cover were analysed. Table 4 shows the changes in the percentage of soil coverage by each plant formation before (PRE) and after fire (POST). These results have been analyzed based on fire severity, site quality, and physiographic factors as slope and aspect. Table 5 summarizes these external factors. Site quality has been assimilated to the amount of vegetation before the fire and discretized into five levels, with the AAA category the highest quality, and the BB the category of lowest quality. Likewise, we have established four levels of severity: high, moderate-high, moderate and low. 
Table 4. Vegetation before and after fire, percentages of land cover changes according to the taxonomic composition (Table 3)

\begin{tabular}{|c|c|c|c|c|c|c|}
\hline PRE POST & $\begin{array}{c}\text { Esparto } \\
\text { grassland }\end{array}$ & $\begin{array}{c}\text { Grass- } \\
\text { shrub }\end{array}$ & $\begin{array}{c}\text { Shru } \\
\text { b }\end{array}$ & $\begin{array}{c}\text { Aleppo pine open } \\
\text { forest }\end{array}$ & $\begin{array}{c}\text { Aleppo pine dense } \\
\text { forest }\end{array}$ & $\begin{array}{c}\text { \% Before } \\
\text { fire }\end{array}$ \\
\hline Esparto grassland & & 93 & & 7 & & $\mathbf{5}$ \\
\hline Grass-shrub & 17 & 35 & 2 & 42 & 4 & $\mathbf{2 9}$ \\
\hline Shrub & 16 & & 80 & 4 & & $\mathbf{3 4}$ \\
\hline $\begin{array}{c}\text { Aleppo pine open } \\
\text { forest }\end{array}$ & & 75 & & 15 & $\mathbf{2 3}$ \\
\hline $\begin{array}{c}\text { Aleppo pine dense } \\
\text { forest }\end{array}$ & 8 & 2 & 20 & 18 & 52 & $\mathbf{9}$ \\
\hline \% Post-fire & $\mathbf{1 0}$ & $\mathbf{4 3}$ & $\mathbf{1 0}$ & $\mathbf{2 5}$ & $\mathbf{1 1}$ & \\
\hline
\end{tabular}

\subsection{Recovery dynamics post-fire vegetation}

From NDVI time series, until eight different patterns or curve types of the dynamics of regeneration of the vegetation structure were identified and defined. The eight characteristic patterns are regarded as 'recovery curves' Figures 1-2 grouped the individual behaviours of all analyzed pixels. In particular, Figure 1 shows for the less mature plant formations (i.e. Esparto grassland, Grass-Shrub and Shrub) these recovery curves in relation to post-fire vegetation, site quality conditions and fire severity, factors which modulate the recovery dynamics.

Table 5. Pre and post fire vegetation, site quality, fire severity, altitude and $\mathrm{dNBR}$.

\begin{tabular}{|c|c|c|c|c|c|}
\hline Pre-fire vegetation & Post-fire vegetation & $\begin{array}{c}\text { Site } \\
\text { quality }\end{array}$ & $\begin{array}{l}\text { Altitude } \\
(\mathbf{m})\end{array}$ & Severity & dNBR \\
\hline \multirow[b]{2}{*}{ Esparto grassland } & Grass-shrub & $\mathrm{BB}$ & $530 \pm 30$ & Low & $160 \pm 30$ \\
\hline & $\begin{array}{l}\text { Aleppo pine opened } \\
\text { forest }\end{array}$ & $\mathrm{BB}$ & $461 \pm 15$ & Low & $197 \pm 10$ \\
\hline \multirow{5}{*}{ Grass-shrub } & Esparto grassland & B & $630 \pm 90$ & Low & $220 \pm 70$ \\
\hline & Grass-shrub & B & $530 \pm 80$ & Low & $240 \pm 70$ \\
\hline & Shrub & $\mathrm{A}$ & $690 \pm 60$ & Mod-Low & $330 \pm 60$ \\
\hline & $\begin{array}{l}\text { Aleppo pine opened } \\
\text { forest }\end{array}$ & B & $530 \pm 40$ & Mod-Low & $280 \pm 80$ \\
\hline & $\begin{array}{l}\text { Aleppo pine dense } \\
\text { forest } 30 \%\end{array}$ & AAA & $780 \pm 30$ & Mod-Low & $370 \pm 80$ \\
\hline \multirow{3}{*}{ Shrub } & Esparto grassland & B & $530 \pm 50$ & Low & $200 \pm 50$ \\
\hline & Shrub & B & $530 \pm 50$ & Low & $220 \pm 70$ \\
\hline & $\begin{array}{l}\text { Aleppo pine opened } \\
\text { forest }\end{array}$ & AA & $585 \pm 15$ & Mod-Low & $354 \pm 7$ \\
\hline \multirow{3}{*}{$\begin{array}{l}\text { Aleppo pine opened } \\
\text { forest }\end{array}$} & Grass-shrub & $\mathrm{B}$ & $550 \pm 70$ & Low & $200 \pm 60$ \\
\hline & $\begin{array}{l}\text { Aleppo pine open } \\
\text { forest }\end{array}$ & B & $570 \pm 70$ & Low & $260 \pm 80$ \\
\hline & $\begin{array}{l}\text { Aleppo pine dense } \\
\text { forest } 30 \%\end{array}$ & B & $580 \pm 50$ & Low & $220 \pm 50$ \\
\hline \multirow{2}{*}{$\begin{array}{l}\text { Aleppo pine dense } \\
\text { forest } 30 \%\end{array}$} & Shrub & $\mathrm{BB}$ & $510 \pm 15$ & Low & $144 \pm 24$ \\
\hline & $\begin{array}{l}\text { Aleppo pine dense } \\
\text { forest } 30 \%\end{array}$ & A & $514 \pm 7$ & Mod-Low & $283 \pm 4$ \\
\hline \multirow{3}{*}{$\begin{array}{l}\text { Aleppo pine dense } \\
\text { forest } 60 \%\end{array}$} & Esparto grassland & $\mathrm{B}$ & $640 \pm 110$ & Baja & $260 \pm 130$ \\
\hline & Grass-shrub & $\mathrm{BB}$ & $470 \pm 20$ & Low & $202 \pm 8$ \\
\hline & $\begin{array}{l}\text { Aleppo pine opened } \\
\text { forest }\end{array}$ & AA & $500 \pm 50$ & Mod-Low & $360 \pm 170$ \\
\hline
\end{tabular}




\begin{tabular}{|l|l|c|c|c|c|}
\hline & $\begin{array}{l}\text { Aleppo pine opened } \\
\text { forest }\end{array}$ & AA & $730 \pm 30$ & Mod-Low & $380 \pm 90$ \\
\hline $\begin{array}{l}\text { Aleppo pine dense } \\
\text { forest 30\% }\end{array}$ & B & $770 \pm 18$ & Mod-Low & $280 \pm 9$ \\
\hline $\begin{array}{l}\text { Aleppo pine dense } \\
\text { forest 30\% }\end{array}$ & AAA & $680 \pm 60$ & Mod-High & $400 \pm 100$ \\
\hline $\begin{array}{l}\text { Aleppo pine dense forest } \\
60 \%\end{array}$ & AA & $696 \pm 24$ & Mod-Low & $350 \pm 60$ \\
\hline
\end{tabular}

Pre-fire vegetation:

'Esparto grassland' \& 'Grass-Shrub' \& 'Shrub'

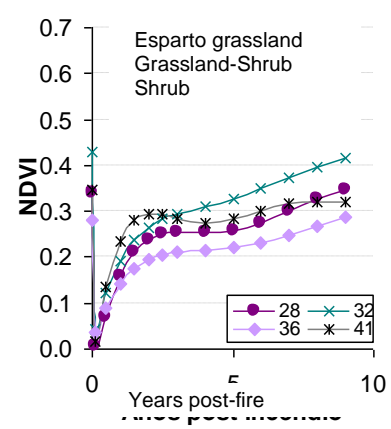

(1a)

Esparto grassland Grassland-Shrub Shrub

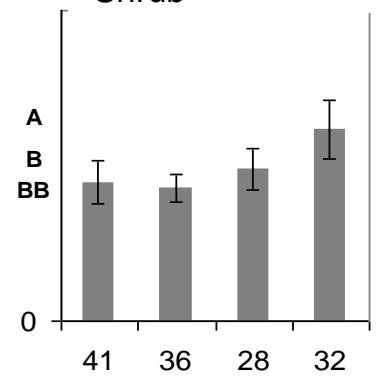

(1d)

Esparto grassland Grassland-Shrub Shrub

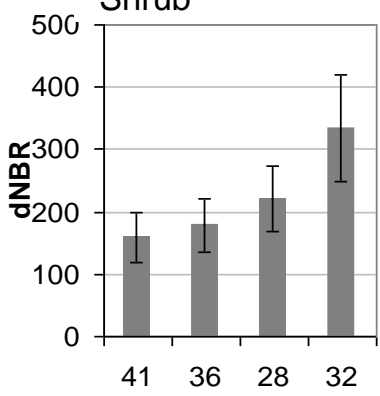

(1g)

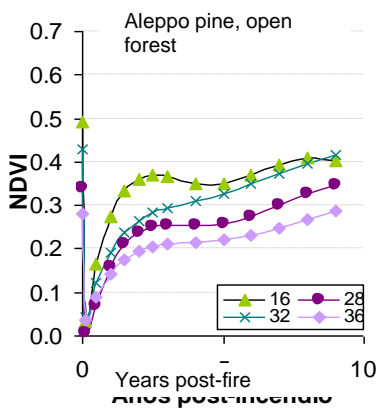

(1b)

Aleppo pine, open forest

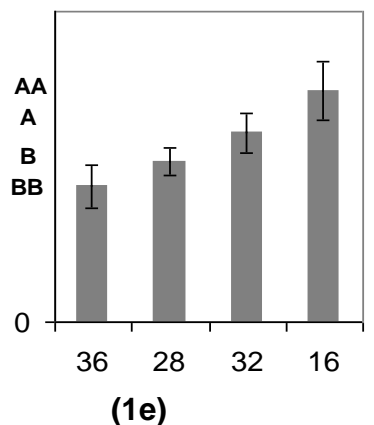

Aleppo pine, open forest

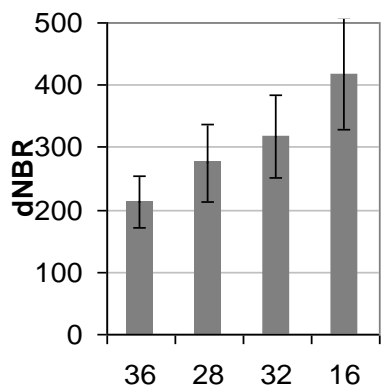

(1h)

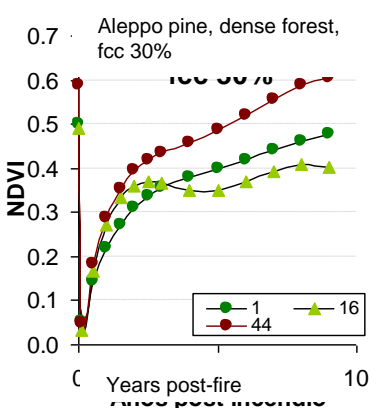

(1c)

Aleppo pine, dense forest, fcc $30 \%$

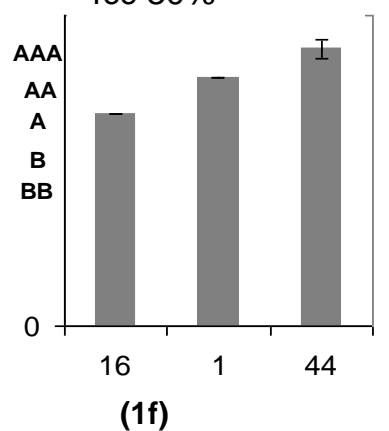

Aleppo pine, dense forest, fcc $30 \%$

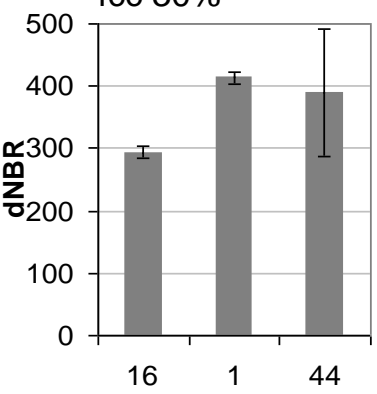

(1i)

Figures 1a-1c: Recovery curves of the original vegetation formations: Esparto grassland, Grassland-Shrub and Shrub after fire: (1a) Esparto grassland, Grassland-Shrub and Shrub; (1b) Aleppo pine open forest; y (1c) Aleppo pine dense forest with canopy cover fraction of $30 \%$. Figures 1d-1f: Quality site. Figures 1g-1i: Average and standard deviation of fire severity $(d N B R)$. 
Pre-fire vegetation:

'Aleppo pine, dense forest, fcc $60 \%$

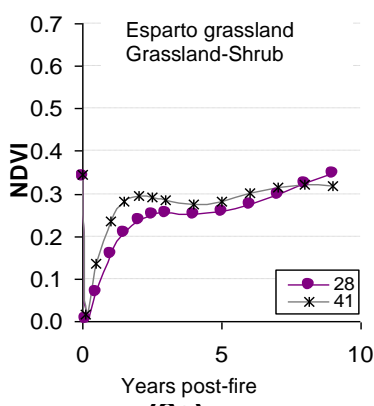

(2a)

Esparto grassland Grassland-Shrub Shrub

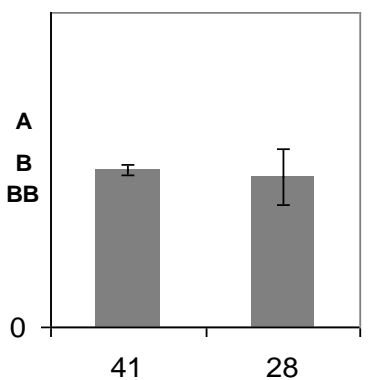

(2e)

Esparto grassland Grassland-Shrub Shrub

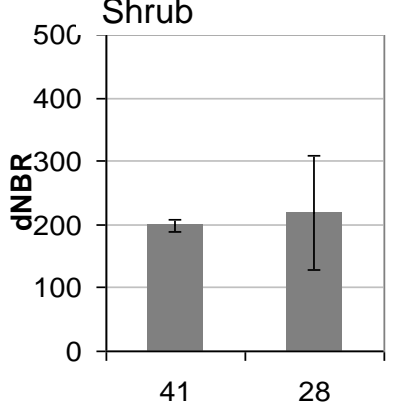

(2i)

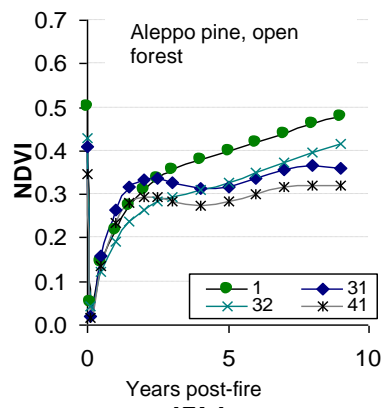

(2b)

Aleppo pine, o open forest

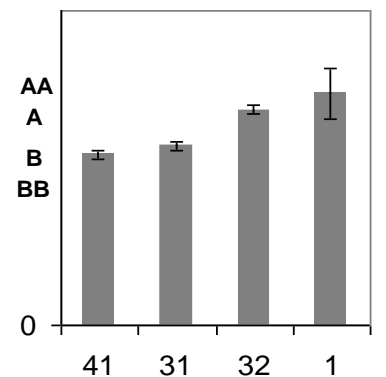

(2f)
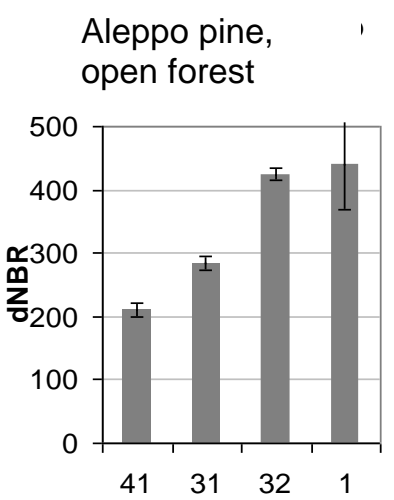

(2j)

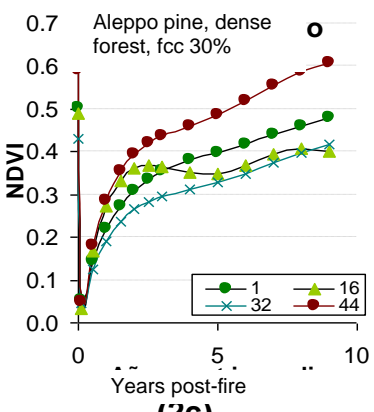

(2C)

Aleppo pine, dense forest, fcc $30 \%$

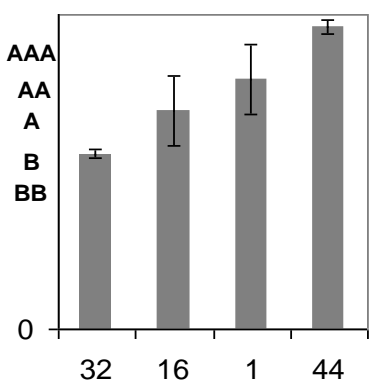

(2g)

Aleppo pine, dense forest, fcc $30 \%$

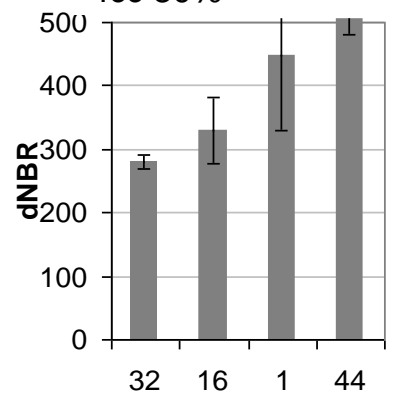

(2k)

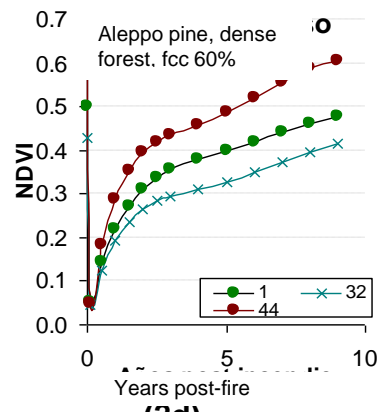

(2d)

Aleppo pine, dense forest, fcc $60 \%$

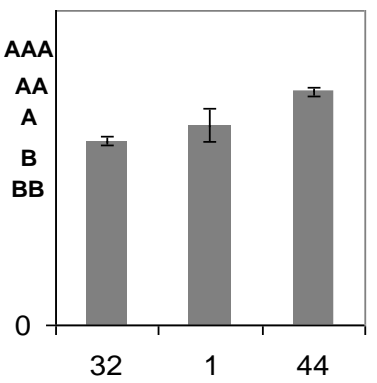

(2h)

Aleppo pine, , dense forest, fcc $60 \%$

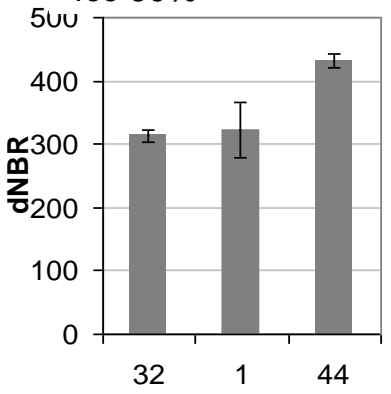

(2I)

Figures 2a-2d: Recovery curves of the original vegetation formations: Esparto grassland, Grassland-Shrub and Shrub after fire: (2a) Esparto grassland, Grassland-Shrub and Shrub; (2b) Aleppo pine opened forest; (2c) Aleppo pine dense forest with canopy cover fraction of $30 \%$ and $(2 d)$ Aleppo pine dense forest with canopy cover fraction of $60 \%$. Figures 2e-2h: Quality site. Figures 2i-2l: Average and standard deviation of fire severity (dNBR).

\section{Discussion}

Immature formations mainly predominate in the study area, which is coherent in a semiarid climate. Indeed, there is no climacic vegetation (Rhamno lycioidis-Quercetum cocciferae sigmetum) in the area, regressive climax only. About 33\% of the pre-fire vegetation changed to regressive stages of autosuccession, one third of vegetation remained in the same successional stage after disturbance and other 33\% developed in a more mature successional stage. Surface of Esparto grassland increased based in changes of its spatial distribution. In most of Esparto grasslands before fire, we recorded regeneration of Aleppo pine after fire. However, shrublands and open marginally in Aleppo pine forest before fire regenerated as Esparto grass. In a similar way, surface of shrubland increased after fire. We 
found similar surface of Aleppo pine forest pre and post-fire. The low site quality in semiarid Mediterranean stands promoted an unstable equilibrium. In this case, fire severity is a key variable influencing recovery after fire.

Related to the dynamics of the structure recovery, patterns are related to the post-fire vegetation. Aleppo pine dense forest with a canopy cover fraction of $60 \%$ showed three different patterns being the resulting post-fire vegetation the same. For the same vegetation formation and canopy cover fraction, curve 44 in comparison with curves 1 and 32, would correspond to vegetation with higher greenness. Moreover, low quality site areas showed the 1998 and 1999 drought effect, as can be seen in the $16,31,28$ and 41 curves.

\section{Conclusions}

The methodology is suitable for the evaluation of the evolution of regeneration of forests after fire. The first results of this study allow us to distinguish areas with different "characteristic curves". This kind of study is interesting for decision making, aimed to optimize resources and improve the management of burned areas. Forest external factors, such as fire severity, site quality or physiography are determinants to post-fire resilience. This contribution is a first step to develop a methodology based on both, fire and recovery sensitive to contextualize short and medium-term change with respect to any potential or desired pre-wildfire stand condition.

\section{Acknowledgements}

This work has been possible thanks to funding by the Ministry of Education and Science of CastillaLa Mancha (Ref. PBCC08-0109); the Ministry of Science and Technology under the National R + D + I, Ingenio 2010 (Ref. CSD2008-00040); and the Ministry of Science and Innovation (MICINN) cofinanced by ERDF (Ref. AGL2011-27747).

\section{References}

Broncano MJ, Retana J, Rodrigo A (2005) Predicting recovery of Pinus halepensis forests after a large wildfire in the northeastern Spain. Plant Ecol 180: 47-56.

De Las Heras, J, Moya, D, Vega, JA, Daskalakou, E, Ramón Vallejo, V, Grigoriadis, N, Tsitsoni, T, Baeza, J, Valdecantos, J, Fernández, C, Espelta, J and Fernandes, P. 2012. Post-Fire Management of Serotinous Pine Forests. En Post-Fire Management and Restoration of Southern European Forests. Moreira, F.; Arianoutsou, M.; Corona, P.; De las Heras, J. (Eds.). Series: Managing Forest Ecosystems, Vol. 24

Díaz-Delgado, R., Lloret, F., Pons, X. Y Terradas, J. (2002). Satellite evidence of decreasing resilience in Mediterranean plant communities after recurrent wildfires. Ecology 83 (8): 2293-2303.

Fox, B.J. Y Fox, M.D. 1986. Resilience of animal and plant communities to human disturbance. In"Resilience in Mediterranean-type ecosystems". (Ed. B.Dell, A.J.M. Hopkins and B.B. Lamont). (Junk, Dordrecht). pp. 39-64.

Holling, C.S. 1973. Resilience and stability of ecological Systems. Annu. Rev. Ecol. Syst. 4 (1): 1-23. doi:10.1146/annurev.es.04.110173.000245.

IFN2. Segundo Inventario Forestal Nacional. Servicio de Inventario Forestal. Dirección General de Medio Natural y Política Forestal. Ministerio de Medio Ambiente, y Medio Rural y Marino.

IFN3. Tercer Inventario Forestal Nacional. Servicio de Inventario Forestal. Dirección General de Medio Natural y Política Forestal. Ministerio de Medio Ambiente, y Medio Rural y Marino.

IGME, 2013, Mapa de litologías de España 1/1.000.000. 
Keeley J.E. 1986. Resilience of Mediterranean shrub communities to fire. In: Dell B, AJM Hopkins \& BB Lamont (eds.). Resilience in Mediterranean-type ecosystems: 95-112. Dr. W. Junk, Dordrect, The Netherlands.

Key CH, Benson NC. 2006. Landscape Assessment (LA). In 'FIREMON: Fire Effects Monitoring and Inventory System'. (Eds DC Lutes, RE Keane, JF Carati, CH Key, NC Benson, LJ Gangi) USDA Forest Service, Rocky Mountains Research Station General Technical Report RMRS-GTR-164CD. p. LA-1-55. (Fort Collins, CO).

Lloret, F.; 1998. Fire, canopy cover and seedling dynamics in Mediterranean shrubland of northeastern Spain. Journal of Vegetation Science 9:417-430.

Moya, D., Espelta, J. M., López-Serrano, F. R., Eugenio, M. And De Las Heras, J. (2008a). Natural post-fire dynamics and serotiny in 10-year-old Pinus halepensis Mill stands along a geographic gradient. International Journal Wildland Fire, 17(2):287-292.

Pausas, J.G. (2004). La recurrencia de incendios en el monte mediterráneo. En Avances en el estudio de la gestión del monte mediterráneo (Vallejo, V.R. y Alloza, J.A. Eds.). CEAM, Valencia, 47-64.

Pimm, S.L. 1984. The complexity and stability of ecosystems. Nature 307:321-6.

Quijada-RoSAS, M. 1992. Glosario de Términos de Genética, Fitogenética y Afines. Universidad de los Andes. Mérida. Venezuela. 436 pp.

Ruiz De La Torre, J. Mapa Forestal De España. Escala 1:200.000. Dirección General de Medio Natural y Política Forestal. Ministerio de Medio Ambiente, y Medio Rural y Marino. Memoria General. ISBN: 84-85496-63-9.

Trabaud, L. 1993. From the cell to the atmosphere: an introduction to interactions between fire and vegetation In: L. Trabaud \& R. Prodon (eds.), Fire in mediterranean Ecosystems: 13:12. CEC-DG XII/D-1. Brussels.

Valladares, F. 2004. Capítulo 4. Lloret, F. Ecología del bosque mediterráneo en un mundo cambiante. Páginas 101-126. Ministerio de Medio Ambiente, EGRAF, S. A., Madrid. ISBN: 84-8014-552-8.

Westman, W. E., And J. F. O'leary. 1986. Measures of resilience: the response of coastal sage scrub to fire.Vegetatio 65(3): 179-189. 